\title{
ULTRASTRUCTURE OF THE ENDOSYMBIOTIC DINOFLAGELLATE Symbiodinium microadriaticum LIVING IN THE SEA ANEMONE Anemonia viridis
}

\author{
by
}

SUHARSONO ${ }^{1)}$

\begin{abstract}
The zooxanthella, Symbiodinum microadriaticum, an endosymbiotic dinoflagellate shows variation in its ultrastructure within its population in the sea anemone, Anemonia viridis. Such variation included the number of thylakoid, the structure of inclusions and the structure of amphiesma. The string-like structure was also found in the nucleoplasm. Some zooxanthellae have a branching or double pyrenoid with two or three stalks. Under certain condition, which are not clearly understood, two or three zooxanthellae are enclosed within one very thick membrane.
\end{abstract}

\begin{abstract}
ABSTRAK
Dinoflagellata, Symbiodinium microadriaticum, yang bersimbiose dengan sea anemone, Anemonia viridis, mempunyai ultrastruktur yang sangat bervariasi. Variasi ultrastruktur melipiiti jumlah tilakoid, struktur inklusionis dan struktur amphiesma. Struktur berbentuk seperti benang juga ditemukan di dalam plasma inti. Beberapa zooxanthella juga mempunyai pirenoid kembar atau bercabang dengan dua atau tiga tangkai pirenoid. Pada kondisi tertentu juga ditemukan adanya dua atau tiga zooxanthellae terbungkus dalam satu dinding sel yang sangat tebal.
\end{abstract}

\section{INTRODUCTION}

Endosymbiotic dinoflagellates, commonly called "Zooxantellae", are found in a wide range of marine invertebrates (TRENCH 1987). At least 80 host species, belonging to three phyla have been shown to be associated with zooxanthella (TAYLOR 1974). As well as adopting a wide range of host speciest, zooxanthellae also possess an extensive geographic range. However, the majority of symbiotic dinoflagellates found in tropical regions are associated with reef building corals.

Endosymbiotic zooxanthellae are unicellular, cocoid in shape, usually brown in colour and are located within host cells. They possess permanently condensed chromo somes visible as oval or circular forms. Chromosomes show no separation during rtie megaphase stage of division and the chromosomes also lack of centriole (TAYLOR 1979).

1) Research and Development Centre for Oceanology—LIPI, Jakarta, Indonesia. 


\section{SUHARSONO}

The morphology and life cycle of cultured cells are different from insitu symbionts (FREUDENTJAL 1962, TRENCH 1987). In axenix media, zooxanthellae become motile cells for certain periods of time. The motile cell has two flagela which emerge at the junction between the longitudinal and transverse furrow in the cell suface; one flagellum extends along each furrow (FREUDENTHAL 1962, SMITH and DOUGLAS 1979).

The question of taxonomy of zooxanthellae remains controversial and problematic. There have been several proposals to resolve this problem, but there is no universal agreement. The first major step in zooxanthellae taxonomy was made by MclAUGHLIN and ZAHL(1957) who were successful in isolating algal cells from the Caribbean jellyfish Cassiopeia. The symbiotic alga was kept in axenix culture media and was described as Symbiodinium adriaticum (McLAUGHLIN and ZAHL 1959). Based on the life cycle and morphology of algae from Cassiopeia sp., FRUDENTHAL (1962) proposed a new genus of Symbiodinium with the type species Symbiodinium microadriaticum. The reason for the new name was that it represents a more logical taxon among the algae group; the dominant stage of this alga appearing to be a vegetative cell or cyst rather than the motile stage. Many authors subsequently have used Symbyidinium (= Gymnodinium microadriaticum Freudenthal, as a compromise to include endosymbiotoc stages or zooxanthellae and motile free-living stages (SCHOEN-BERG and TRENCH 1976, 1980; FITT et al 1981). TAYLOR (1971) observing living Velella from Florida, found that endosymbiotic algae possessed two tylakoid lamellae instead of usual three or more. Evidence of a girdle lamellae was also recorded in this alga. Subsequently this alga was described as Enclodinium chattonii (Hovasse). TAYLOR (1971) also proposed a new generic name Gymnodinium, for amended Symbiodinium microadriaticum Freudenthal. Furhter changes were proposed by LOEBUCH and SHERLEY (1979) in which Symbyodinium of Freudenthal was placed in synonimy with zooxanthella with the species name of Zooxanthella microadriatica (Freudenthal). The reason for the proposed changes by LOEBLICH and SHERLEY (1979) was based on the ultrastructure of the theca of the symbiotic alga associated with the red alga, Chondrus crispus (L.) from Sippewissett, Massachusetts. They found that S. microadriaticum differed slightly from the type species Zooxanthella nutricula and It was considered that Symbiodinium should be a subjective synonym of Zooxanthella.

Many investigators are aware that the wide geographic range of ecological distribution for a single species of $S$. microadriaticum is relatively uncommon (TAYLOR 1969; SCHOENBERG and TRENCH 1976, 1980). The similarity of the morphology and ultrastructure of symbiotic algae might not be sufficient to distinguish between strains or varietes of S. microadriaticum. Fundamental difference have been found among algae harboured both by different hosts and by the same host in different geographic locations (BLANK and TRENCH 1985, BLANK 1986),

The aim of this study is to examine variation in the morphology of endosymbiotic 
Ultrastructure Of The Endosymbiotic Dinoflagellate ... (Suharsono)

Endosymbiotic Dinoflagellate

S. microadriaticum in the sea anemone Anemonia viridis, in order to ascertain the possibility of the existance of different strains or varieties of S. microadriaticum.

\section{MATERIALS AND METHODS}

Intertidal Anemonia viridis Forskal were collected from Plymouth on the south west coats of England. Anemones were maintained in an aquarium with recirculating sea water and kept at $16^{\circ} \mathrm{C}$. The anemones were fed with Artemia larvae, twice weekly. Anemones were maintained for seven days to acclimitize to laboratory conditions before experimental use.

\section{TRANSMISSION ELECTRON MICROSCOPY}

Sea anemones were anaesthetized in a $1: 1$ solution of $0.3 \mathrm{Mg}_{2}, \mathrm{H}_{2} \mathrm{O}$, and sea water for about 20 minutes. Tentacles and mesenterial filaments were cut into small pieces and fixed in $3 \%$ gluteraldehyde, $0.5 \%$ tannic acid, and $8.5 \%$ sucrose in $0.1 \mathrm{M}$ sodium cacodylate buffer solution for one hour at room temperature, followed by 14 hours at $4^{\circ} \mathrm{C}$. Specimens were then rinsed for one hour in sodium cacodylate buffer and post-fixed in $1 \%$ osmium tetroxide in sodium cacodylate buffer for on? hour, at room temperature. Specimens were subsequently rinsed in cacodylate buffer followed by dehydration in graded series of acetones. Infiltration with Emix resin was performed in several changes and then blocks were stored overnight. The specimens were embedded in Emix resin and polymerization carried out at $60^{\circ} \mathrm{C}$ for 48 hours. Serial ultrathin section 60-70 nm were cut on an LKB microtome using glass knives. Sections were mounted on copper filmed grids and stained using aquous uranyl acetate for 30 minutes at $40^{\circ} \mathrm{C}$ and lead citrate for 20 minutes at $20^{\circ} \mathrm{C}$, using an LKB 2168 ultrastainer. Sections were viewed in a Kraton Cora transmission, electron microscope at an accelerating voltage of $80 \mathrm{KV}$.

\section{STAINING FOR CARBOHYDATES}

Carbohydates were stained using a technique developed by COURTOY and SIMAR (1974). Thin sections were mounted on gold grids and exposed to $1 \%$ periodic acid for 25 minutes at room temperature. Sections were then washed with distilled water. Sections were subsequently treated with thiosemicarbazide solution for 30-45 minutes at room temperature, washed with an acetic acid series, followed by washing with distilled water. Following this treatment section were stained in silver proteinate at room temperature for 30 minutes in the dark room and were then washed in distilled water and allowed to dry. 


\section{SUHARSONO}

\section{SCANNING ELECTRON MICROSCOPY}

Sea anemones were anaesthetized in a $1: 1$ solution of $03 \mathrm{M} \mathrm{MgCl}_{2}, 6 \mathrm{H}_{2} \mathrm{O}$, and tea water for about 30 minutes. Tentacles were cut into $0.5 \mathrm{~cm}$ length and fixed in 5\% formaldehyde overnight, followed by dehydration in a graded series of acetones; they were then stored overnight at $4^{\circ} \mathrm{C}$. Specimens were subsequently air dried and fractured with a razor blade. They were then coated with gold palladium using an ion coater (Polaron E 5100). Specimens were observed with a scanning electron microscope (JeoL JSM SI) operated at $15 \mathrm{kV}$.

\section{RESULTS}

In situ studies show zooxanthellae in the endodermal lining of the tentacles and mesenterial filaments of Anemonia viridis. The algal cells are located intracellularly and are present in individual vacuoies within the cyptoplasm at the bases of the endodermal cells (Figure 1). The vacuole membrane of the host cell is usually in close contact with the algal surface/However there is sometimes a gap between them. The typical appearance of zooxanthellae in fixed specimens of A viridis is of a rounded cell with diameter of 5-8 microns. Freshly isolated zooxanthellae are 7-11 microns in diameter. Observations of the surface of zooxanthellae, using scanning electron microscopy; show that the surface of the cell wall is smooth in appearance (Figure 2).

The general appearance of the internal structure of mature zooxanthellae is shown in Figure 3. They posses $r$ elatively thin walls, and a nucleus with condensed chromosomes which is typical of the dinoflagellates (TAYLOR 1987). The chloroplast is very obvious and situated near the periphery of the cytoplasm. The most readily iden-tifisable structure is the large flask-like pyrenoid and the accumulation body which a appears black and rounded. Starch grains, calcium oxalate crystals and mitochondria axe distributed in the cytoplasm.

The nucleus varies from being subspherical to spherical in shape with many irregular imaginations of the nuclear membran. The diameter of the nucleus is about 2.5-4 microns and is dependent on the developmental stage of the zooxanthellae. The location of the nucleus is Qff-centre in the cyptoplasm and occasionally the nucleus appears to be in close contact with the cell plasma membrane (Figure 3). The nucleus is surrounded by a porous double membrane. The thickness of the nucleur membrane is $20-33 \mathrm{~nm}$ and the diameter of the nucleur pores is between $83-100 \mathrm{~nm}$. The nu-cleohis is relatively small and located in close contact with the nucleur membrane. The nudeolus contains numerous granules which are densely distributed in both the periphery and in the center of the organella. Chromosomes vary in shape from oval to elongated, consisting of compact coiled spiral chromatin : they are randomly distributed (Figure 4). The nucleoplasm contains numerous dark staining granules and fibrous materials which is evenly distributed in the nucleus. In the nucleoplasm, string-like structures with a diameter of $4-7 \mathrm{~nm}$ are sometimes found grouped together and 
Are randomly distributed. This string is sometimes found in contact with the chromosom or the nucleur membrane. Amorphous bodies are also present in the nucleoplasm (Figure 4).

The chloroplast is the largest structure in the zooxanthellae cell. It is peripheral in position and entirely surrounded by a triple membrane. Serial sections show that the chlorooplast is single and multilobed. The chloroplast contains numerous lamellae which are parallel to the length of the chloroplast. The chloroplast membrane and the nearest lamella membrane are separated by a gap of $0.5 \mathrm{~nm}$ width (Figure 5). The thickness of the chloroplast membranes is about $1.3-1.7 \mathrm{~nm}$, the membrane appears as a heavily staining line (Fire 5). One characteristic of zooxanthellae associated with Anemonia viridis is that they possess a peripheral lamella thightly underlying the chloroplast membrane. The lamella adheres closely to the shape of the membrane. Each lamella consists of three closely associated thylakoide. However two thylakoids can be found in the middle of the chloroplast when one lamella cross links with another (Figure 5). The thickness of the lamella is $40-50 \mathrm{~nm}$ and the thylakoid is $15-17 \mathrm{~nm}$ width. In the middle of the chloroplast the thylakoid tends to be tightly packed whereas in the tip of the chloroplast the thylakoids are much less compact (Figure 5).

The pyrenoid is flask-like structure, protruding from the surface of the inner side of the chloroplast by a short stalk (Figure 6). The pyrenoid is surrounded by a continuation of the chloroplast membrane and is also enclosed by a thick starch sheath which is seen as a halo of electron transculent material. The content of the pyrenoid is uniformly granular material which is not penetrated by the chloroplast lamella (Figure 6). The zooxanthellae in Anemonia normally possesses a single pyrenoid with a single stalk. However some cells have a branching or double pyrenoid with two or three stalks (Figure 6).

The mitochondria vary in shape and in position. They are ovoid to elongate or branching and are surrounded by a double membrane which is $11-12 \mathrm{~nm}$ thick (Figure 7). The internal structure of a mitochondrion consists of microtubular or microvilli-like cristae. The cristae are 33-44 $\mathrm{nm}$ in diameter and are attached to the membrane of the mitochondrion. Cristae are not found in the center of the mitochondrion which consists of amorphous or granular material.

The golgi apparatus is relatively small with 3-5 cisternae about $24 \mathrm{~nm}$ in diameter and $125 \mathrm{~nm}$ length. Small vesicles are scattered close to the Golgi apparatus (Figure 7). There is also a complicated system of microtubules and vesicles which consists of rough or smooth endoplasmic reticulum (Figure 7).

The most easily recognisable feature of the algal cell is the accumulation body, which is large, rounded and possesses a dense outer covering, which is dark and electron dense with some dark patches inside (Figure 8). The remaining inclusions of the cells such as calcium oxalate crystals, starch grains, lipid droplets and microbodies are present in the cyptoplasm (Figure 8). Calcium oxalate crystals are clumped and characterized by rectangular shape (Figure 8). Starch grains are randomly distributed and are recognized by a positive reaction when stained with periodic acid thiosemicarbazide silver 


\section{SUHARSONO}

proteinate (Figure 8). Microbodies are also present, they are rounded in shape and enclosed by a single membrane, $300-500 \mathrm{~nm}$ in diameter. Small vesicles are found between the microbodies. The contents of the microbodies are homogeneous, consisting of amorphous material (Figure 8).

Normally, endosymbiont zooxanthellae possess relatively thin cell walls known as amphiesma (SCHOENBERG and TRENCH 1980). However, in zooxanthellae associated with A. viridis the thickness of the maphiesma varies greatly between 100-730 nm (Figure 9). It seem that the thickness correlated with the condition and developmental stage of the zooxanthellae.

Observation on the untrastructure of the dividing zooxanthellae indicated that the cells undergo cytokinesis within the parent amphiesma. Cytokinesis occurs after caryokinesis (Figure 10). Healthly zooxanthellae divide into equal cells. All organelles in the cell also divide equally between the daughter cells, except for the accumulation body. Serial sections show that only one of the daughter cells has an accumulation body. When the cell undergoes division, it is clear that the membranes of the daughter cells is composed of two layers (Figure 10). Both daughter cells eventually become two individuals after the cells break apart. During further development the cell wall gradually thickens until the algae become mature, after which they discard the thick parent wall. Some algal cells may continue to produce a thick wall and accumulate wastes inside the cytoplasm; such cells subsequently enter a senescent phase which subsequently leads to degeneration.

Figure 11 shows degenerate stages of the zooxanthellae in situ. The first stage of degeneration is characterized by an increase in the amount of calcium oxalate and an enlargement of the accumulation body. This is followed by the disintegration of the chloroplast and nucleus. The chloroplast lamella then between less well structured but the cell wall remains unchanged until complete disintegration occurs. In certain conditions, the cell wall breaks down first, followed by the disintegration of cellular inclusions (Figure 11).

\section{DISCUSSION}

The location of algae in the host tissue varies among invertebrates. KAWAGUTI (1964) found that zooxanthellae associated with some coral species were intercellular, while algae in the bivalve Tridacna were found in blood amoebocytes (FRANKBONER 1971; GOREAU et al 1973). Symbiodinium has also been found intercellularly in the octocorallian, Eunicella (TRENCH 1979); Symbiodinium microadriaticum in the jellyfish, Cassiopeia was located in the mesoglea and was enclosed within wandering cells. In the zoanthied, Protopalythoa sp., zooxanthellae are found in both endoderm and ectocerm (RYLAND, pers. comm.).

The unsual inclusions sometimes found in the nucleoplasm of Symbiodinium associated with $A$. viridis have not been reported previously. A group of string-like structures were also found in the nucleoplasm of the dinoflagellate Prococentrum 
micans (SOYER 1981). Soyer suggested that the string-like structures may play a role both in maintenance of nuclear structure and in chromosomal movement during mitosis. STONE and VESK (1982) found a band of dense gramular material unterlying the nuleur membranes in Gymnodinium splendens. Paracrystalline bodies which have a hexagonal structure, were also found in the dinoflagellate Cyrodinium cohnii (HEINE 1974).

The lamellar arrangement and the number of thylakoids per lamella in the chloro-plast constitute taxonimically important criteria (BLANK 1986). A micrograph by TAYLOR (1968) showed zooxanthellae in Anemonia sulcata (= viridis) which possessed peripheral thlakoids with three closely packed lamellae. However TAYLOR (1986) does not describe these features in detail. In another paper on the symbionts of Velella, TAYLOR (1971) used the characteristic of two thylakoids to establish a new species of dinoflagellate, Endodinium chotonii BLANK (1986) found that zooxanthellae associated with zoanthid, Zoanthus sociatus possessed a peripheral thylakoid triplet which entirely surrounded the chlroplast. In the Carribean jellyfish, Cassiopeia, KEVIN et al (1969) found chloroplast in S. microadriaticum which lacked peripheral thylakoids.

Symbiodinium associated with 27 host species that belong to two phyla has been reported to possess a pyrenoid with one or three stalks (SCHOENBERH and TRENCH 1980), but there are no studies which have described branching pyrenoids or double pyrenoids such as those observed in the present study. The double pyrenoids or branching pyrenoids might be related to early stages of division of this organella.

The structure of the cell wall varied considerably among zooxanthellae observed in A. viridis. SANTORE (1977) investigated the amphiesma of Cryptomonas and suggested that the amphiesma structure had taxonomic importance. SCHOENBERG and TRENCH 1988) studied zooxanthella in vitro from different host species found that different strains of algae demonstrated differences in the details of the structure of the amphiesma.

Differences in the ultrastructure of S. microadriaticum might be due to phenotypic variability rather than genetic differences within the population. Phenotypic variation in dinoflagellates can vary as the result of a number of factors. Variation may occur in the same geographic region at different times of the year or may be observed between populations of the same species in different regions (TAYLOR 1987). Previous investigators found that there were differences in thet morphology of $S$. microadriaticum in different host species and suggested that morphological differences were due to the different stages of development in the dinoflagellate life cycle (TAYLOR 1973; SCHOENBERG and TRENCH 1976; STEELE 1977). SCHOENBERG and TRENCH (1980) compared the ultrastructure of $S$. microadriaticum which were isolated from different hosts and cultured axenically under identical conditions, to determine whether differences in structure were related to genetic differences. They suggested that there were ultrastructural differences between strains from different host species. In the present study, more information has been gathered about $S$. microadriaticum associated 


\section{SUHARSONO}

with $A$. viridis. Results have shown a wide range of variation in zooxanthellae ultra-structure. Direct comparison with type cultures or zooxanthellae cannot be made since, $S$. microadriaticum associated with $A$. viridis from temperate regions has not been succesfully cultured in axenic media. Furthermore no free living stages of the algae have been found.

It is also possible that different strains of $S$, microadriaticum may be found in the same host species. Genetic studies might clarify whether this is the case e.g. : indirect measurement of genetic differences can be carried out by measuring protein variations using gel electrophoresis (SCHOENBERG and TRENCH 1980; AYALA and KIGER 1982); and by encoding the nucleotide sequence of tile DNA of structural genes.

\section{REFERENCES}

AYALA, F.J. and J.A KIGER, 1982. Modem genetics. Benyamin Publ. Co. California : 844 pp.

BLANK, R.J., 1986. Unusual chloroplast structures in endosymbiotic dinoflagellates : a clue to evolutionary differentiation within the genus Symbiodinium (Dino-phyceae). PI Syst. Ecol 151 : $271-280$.

BLANK, R J. and RK TRENCH, 1985. Speciation and symbiotic dinoflagellates. Science 229 : 656-658.

COURTOY, R and L.L SIMAR, 1975. Importance of controls for the demonstration of carbohydrates in electron microscopy with the silver methenamine or the thiocarbohydradrazide-silber proteinate methods. J. Microcospie. $100: 199-211$.

FTTT,W.K., S.S. CHANG, and RK. TRENCH,, 1981. Motility patterns of different strains of symbiotic dinoflagellate Symbiodinium (= Gymnodinium microacria-ticum (Freudenthal) in culture. Bull Mar. Sci. 31: 436-443.

FRANKBONER, P.V., 1971. Intracelliilar digestion of symbiotic zooxanthellae by host amoebocytes in giant clams (Bivalvia : Tridacnidae) with a note on the nutritional role of hypertrophied siplional epidermis. Biol Bull 141 : 222-234.

FREUDENTHAL, H., 1962. Symbiodinium. gen. nov. and S. microadriaticum sp. nov. a zooxanthellae taxonomy life cycle and morphology. J. Protozool ( : 45-57.

GOREAU, T.F., N.L GOREAU and CM YONGE, 1973. On the utilization of photo-synthetic products from zooxanthellae and of dissolved amino acids in Tridacna maxima, F. elongata (Roeding), J. Zool Lond. 169 : 417-454.

HEINE, U.L, 1974. Intranuclear viruses. In : "The nucleus" (H. Bush ed.). Acad Press. New York: 489-536. 
Ultrastructure Of The Endosymbiotic Dinoflagellate ... (Suharsono)

\section{Endosymbiotic Dinoflagellate}

KEVIN, M.J., W.X HALL, JJA McLAUGHLIN and PA ZAHL,, 1969. Symbiodi-nium microadriaticum Freudenthal, a revised taxonomic description, ultra-structure. /. Phycol $5: 341-350$

KAWAGUTI, S., 1964. Zooxanthellae in the corals are intracellular symbiots. Proc. Jap. Acad. Sci. $40: 545-548$.

LOEBLICH, AR, and J.L SHERLEY, 1979. Observation on theca of motile phase of free living and symbiotic isolates of Zooxanthella microadriatica (Freudenthal) comb, nov., $J$. Mar. Biol. Ass. UK : 195-205.

McLAUGHLIN, JJA and AP. ZAHL, 1957. Studies in marine biology II. In vitro culture of zooxanthellae. Proc. Soc. Exp. Biol. Med. 85 : 115-120.

McLAUGHLIN, JJA and AP. ZAHL, 1959. Studies in marine biology III. Axenic zooxanthellae from various hosts. Ann. NY. Acad. Sci. $77: 55-72$.

SANTORE, U.J., 1977. Scanning electron microscopy and comparative micromor-phology of the periplast of Helmiselmis rufescens, Cromonas sp. and members of the genus Cryptomonas (Cryptophyceae). By. Phycol J. 12 : 255-270.

SCHOENBERG, DA and RK. TRENCH, (1976). Specificity of symbiosis between marine cindarians and zooxanthellae. In : "Coelenterata ecology and behaviour". (G.O. Mackie. ed.) Plenum. Press. New York : 423-432.

SCHOENBERG, DA and RK TRENCH,, 1988. Genetic variation in Symbiodinium (= Gymnodinium) microadriaticum Freudenthal and specificity in its symbiosis with marine invertebrates III. Proc. R. Soc. Lond. B. 207 : 445^160.

SMITH, DC and AE DOUGLAS, 1979. The Biology ofsymbioses. Edward Arnold Publ. Australia. 302 pp.

SOYER, M.O., 1981. Presence of intranucleuar microcables in a primitive dinoflagellate protist : morphological description and discussion of their possible evolutionary significance. Biosystem 14 : 299-304.

STEELE, RD., 1972. The significance of zooxanthellae containing pellets extruded by sea anemones. Bull. Mar. Sci. 27 : 591-594.

STONE, J. and M VESK, 1982. Intranucleur microfilaments in a dinoflagellate. Micron 13 : 355336.

TAYLOR, D.L, 1968. In situ studies on the cytochemistry and ultrastructure of a symbiotic marine dinoflagellate. /. Mar. Biol. Ass. UK 48 : 349-366.

TAYLOR, D.L, 1969. On regulation and maintenance of algal numbers in zooxanthellae coelenterate symbiosis. /. Mar. Biol. Ass. U.K. 49 : 1057-1065.

TAYLOR, D.L, 1971. Ultrastructure of the zooxanthellae Endodinium chattonii in situ. J. Mar. Biol. Ass. UK. 51 : 227-234.

TAYLOR, DL, 1973. The cellular interactions of algal invertebrate symbiosis. Adv. Mar. Biol. $11: 1-56$. 


\section{SUHARSONO}

TAYLOR, D.L. 1974. Symbiotic marine algae, taxonomy and biological fitness. In : "Symbioses in the sea" (W.B. Venberg ed.). Univ. Press. South Carolina. 245-262.

TAYLOR, D.L, 1979. Symbioticsms revisited : a discussion of the evolutionary impact of intracellular symbiosis. Proc. R: Soc. Lond. B. 204 : 267-286.

TAYLOR, D.L, 1987. Dinoflagellate morphology. In : "The biology of dinoflagellates" (F.J.R. Taylor, ed.). Blackwell. Sci. Publ. London, 24-92.

TRENCH, RK., 1979. The physiology of plant-animal symbiosis. Ann. Rev. Plant. Physiol. 30:485-531.

TRENCH, RK., 1987. Dinoflagellates in non parasitic symbiosis. In : "The biology of dinoflagellates" (F.J.R. Taylor, ed.) Blackwell. Sci. Publ. London : 530-570. 


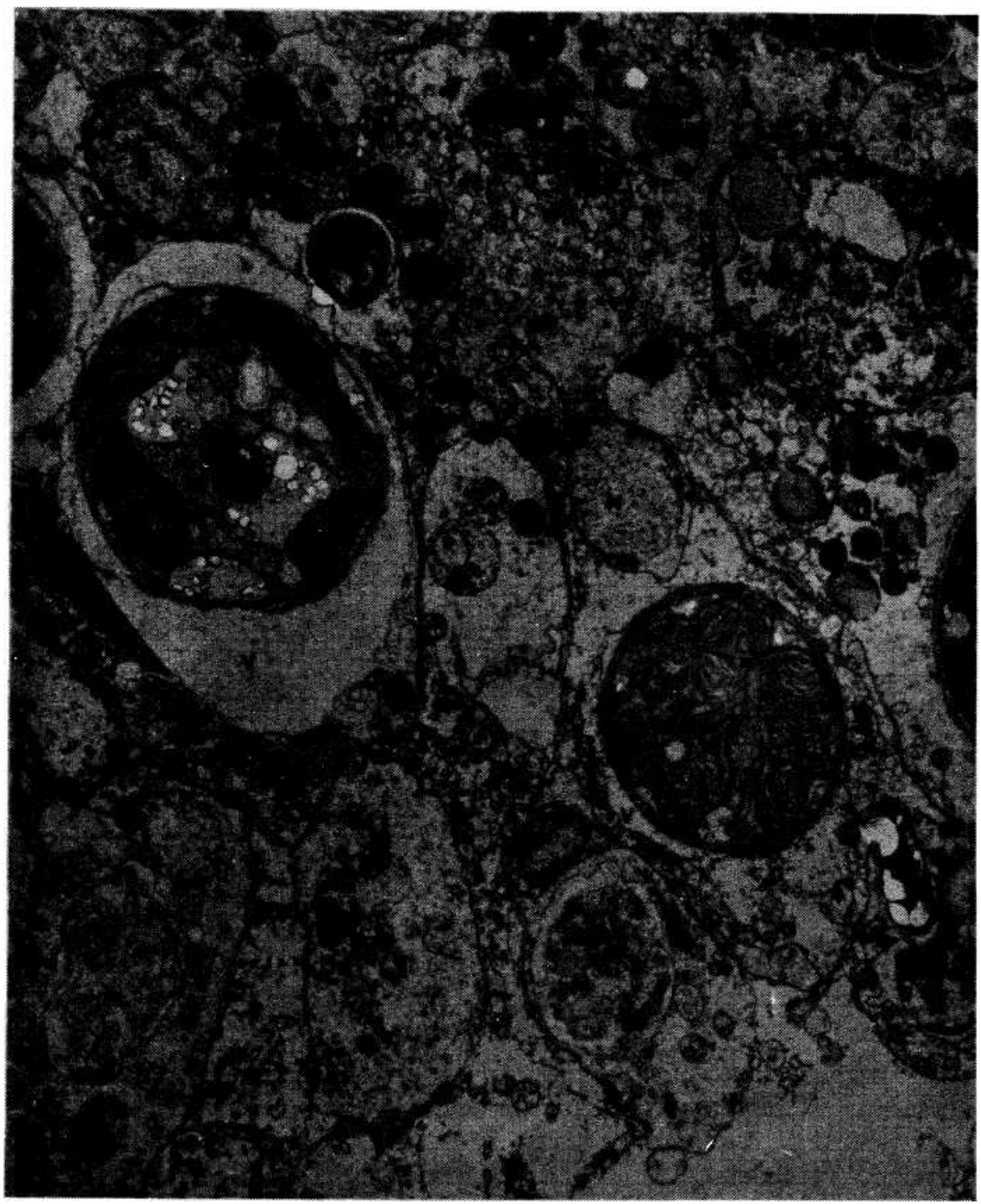

Figure 1. Electron micrograph of a section of the endoderm of Anemonia viridis showing cell features of Symbiodinium microadriaticum enclosed invacuoles within host cells.

$\mathrm{N}$ = nucleus; $\mathrm{V}$ = vacuole; $\mathrm{Z}$ = zooxanthellae.

Scale bar is in microns. 


\section{SUHARSONO}

Figure 2

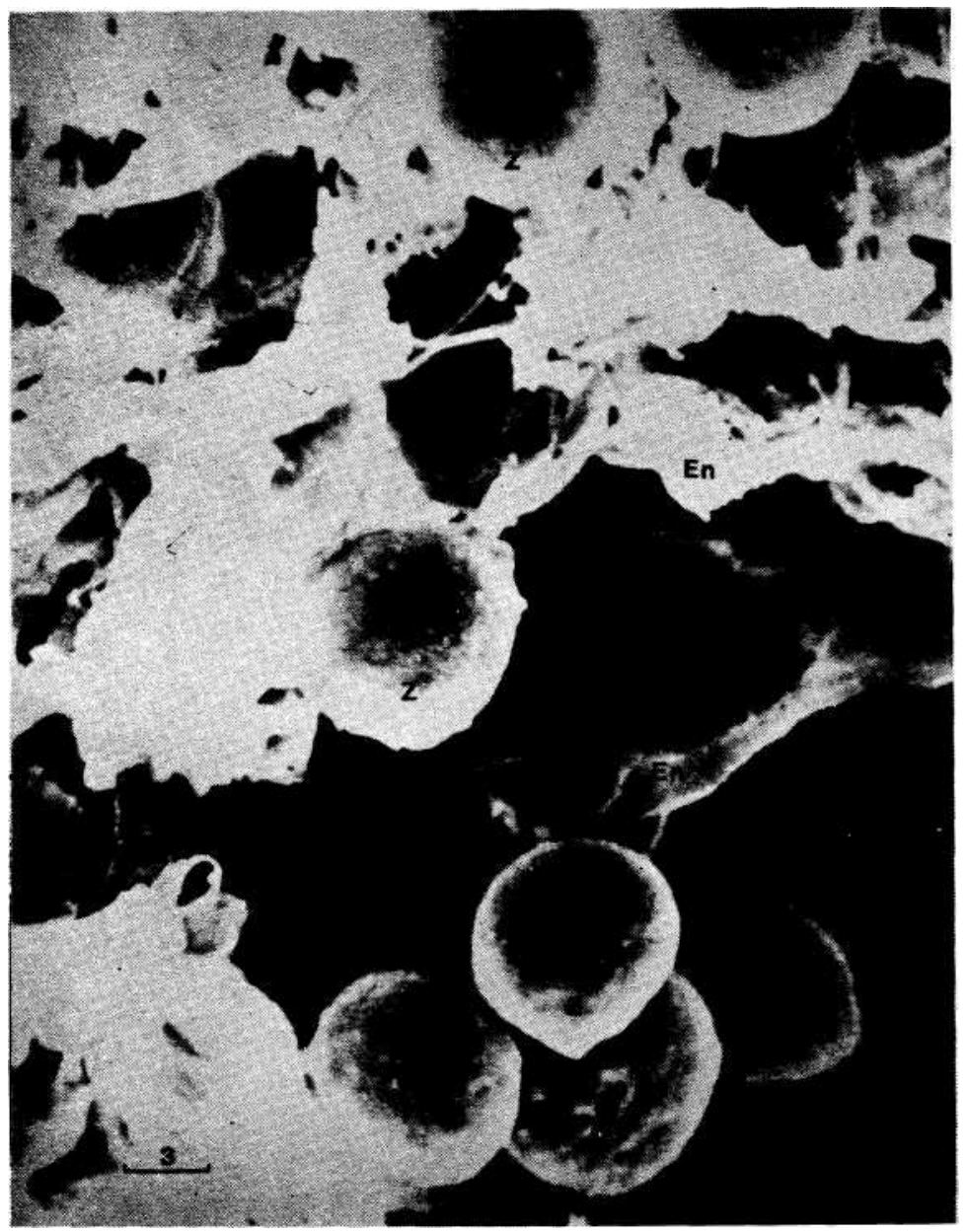

Figure 2. Scanning electron micrograph showing the smooth, surf ace of the cell wall of Symbiodinium microadriaticum in the endoderm of Anemonia viridis. $\mathrm{Z}=$ zooxanthellae; En = endodermal tissue. Scale bar is in microns. 


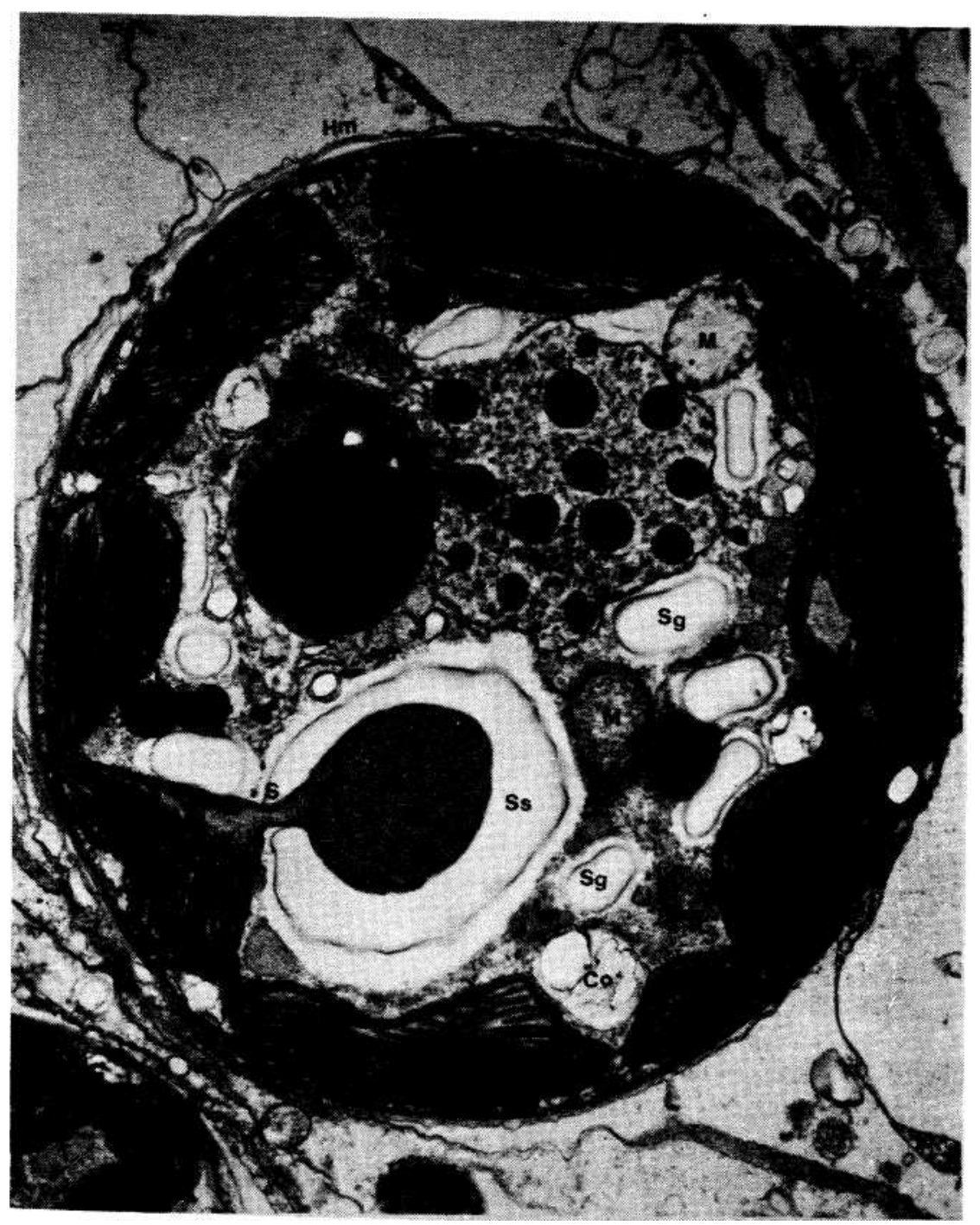

Figure 3. Electron micrograph of Symbiodinium microadriaticum showing the characteristic appearance of the healthy cell.

$\mathrm{Ab}=$ accumulation body; $\mathrm{Cl}=$ chloroplast; $\mathrm{Co}=$ calcium oxalate crystal; $\mathrm{Cr}=$ chromatin; $\mathrm{Hm}=$ host cell membrane; $\mathrm{L}=$ pyrenoid; $\mathrm{S}=$ stalk; $\mathrm{Sg}=$ starch grain; $\mathrm{Ss}=$ starch sheat; $\mathrm{Zm}=$ zooxanthellae membrane . Scale bar is in microns. 


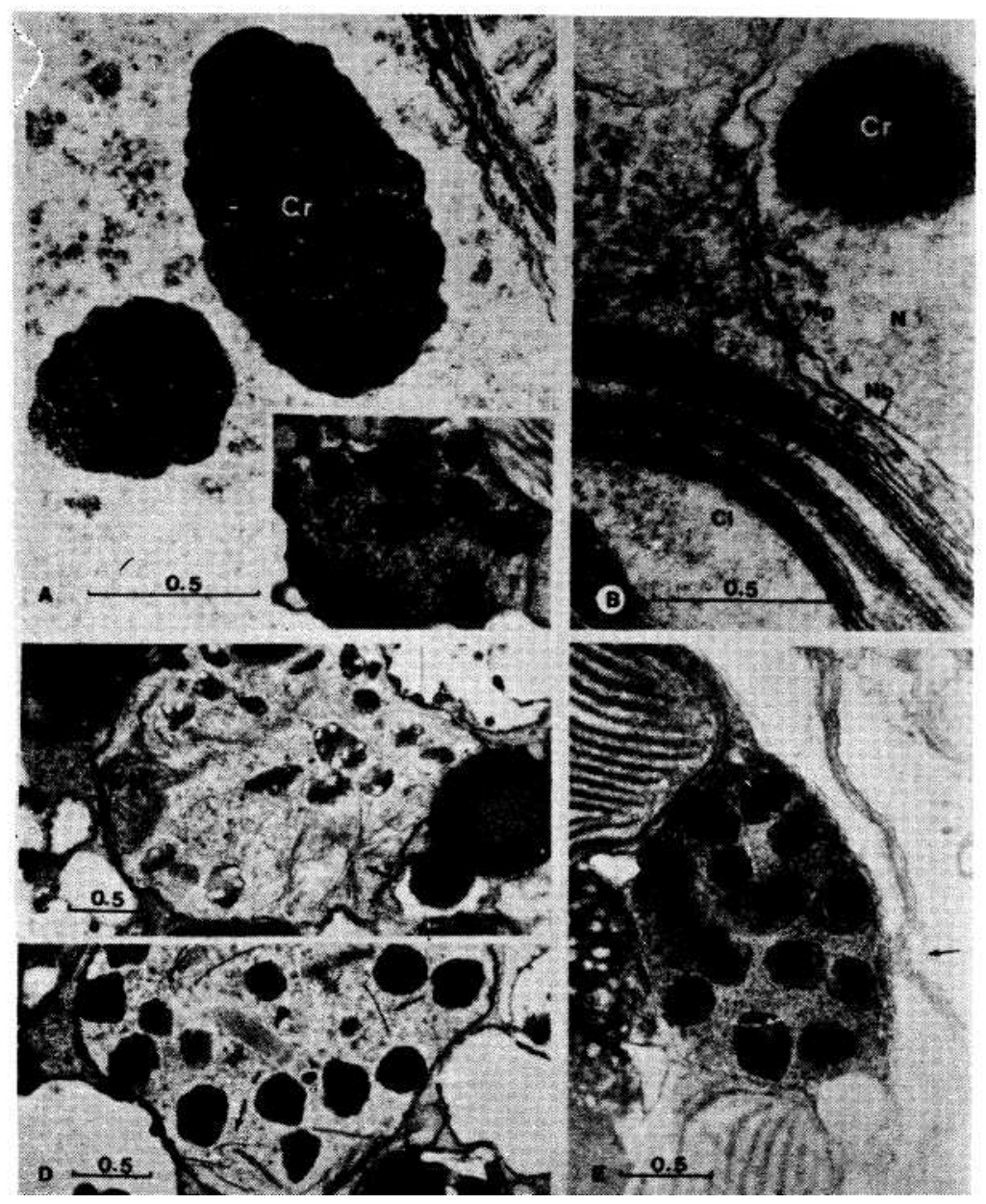

Figure 4. Electron micrograph showing the nucleus of Symbiodinium microadriaticum displaying : A. Densely coiled chromatin and the nucleolus (insert) in close contact with the nucleur membrane; B. A double nucleur membrane indicated by arrow $(\mathrm{Nb})$ and pores of the nucleus envelope also indicated by arrow (Np); C. A bundle of string-like structure indicated by arrow; D. A string-like structure indicated by arrow and arrow head showing amorphous body; E. Nucleus of zooxanthellae in close contact with algal cell wall which is indicated by an arrow.

$\mathrm{Cl}=$ Chloroplast $\mathrm{Cr}=$ chromosome; $\mathrm{Cw}=$ cell wall; $\mathrm{N}=$ nucleus; $\mathrm{Nb}=$ nucleur pore.

Scale bar is in microns. 


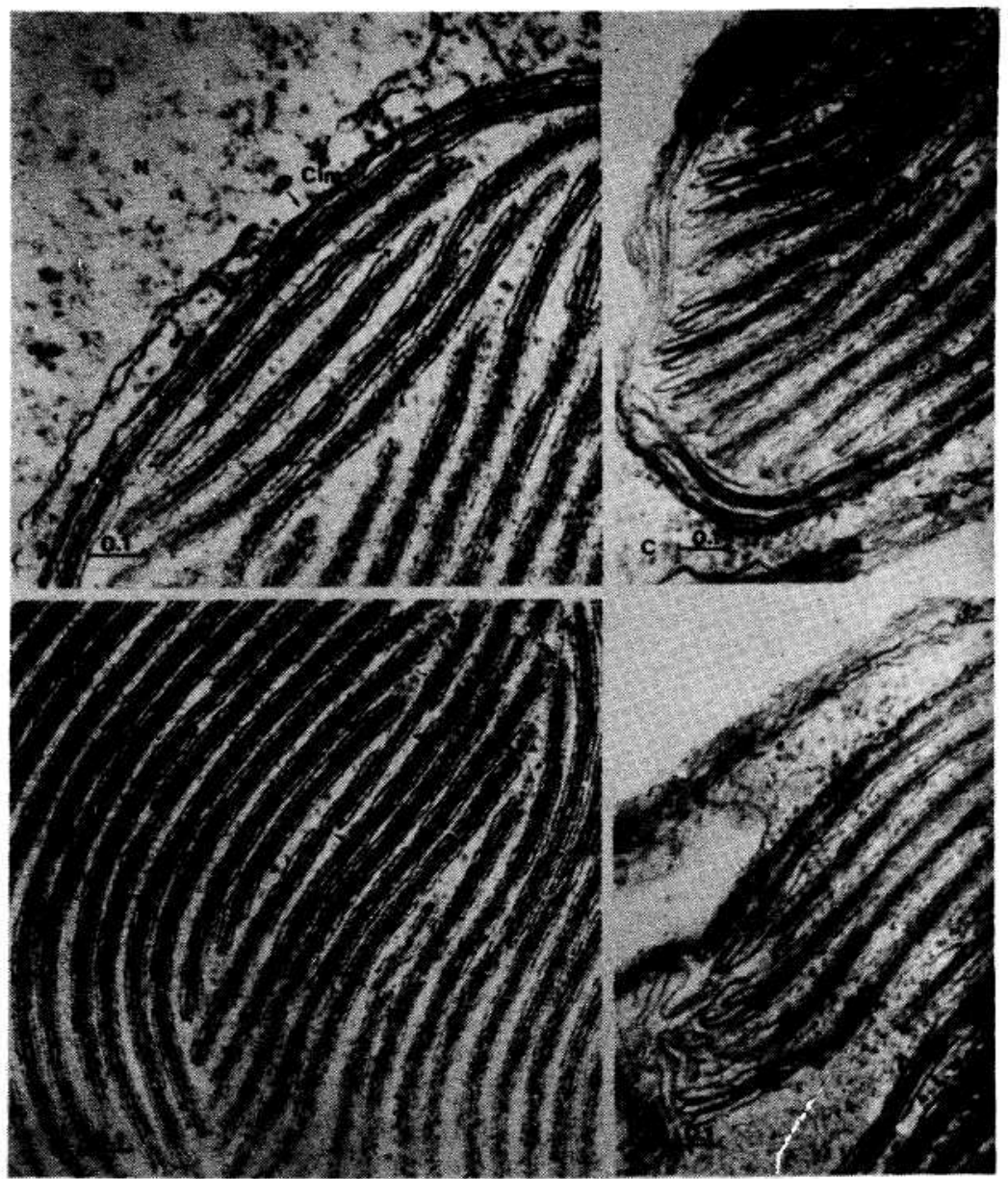

Figure 5. Electron micrograph of chloroplast of S. microadriaticum showing : A The structure of the peripheral lamella which indicates that each lamella consists of three thylakoids; B. Arrow showing lamella which consists of two thylakoids; C and D. Lamellae in the tip of Chloroplast are loosely packed. $\mathrm{L}=$ lamella; $\mathrm{N}=$ nucleus; $\mathrm{T}=$ thylakoid; $\mathrm{Clm}=$ chloroplast membrane. Scale bar is in microns. 


\section{SUHARSONO}

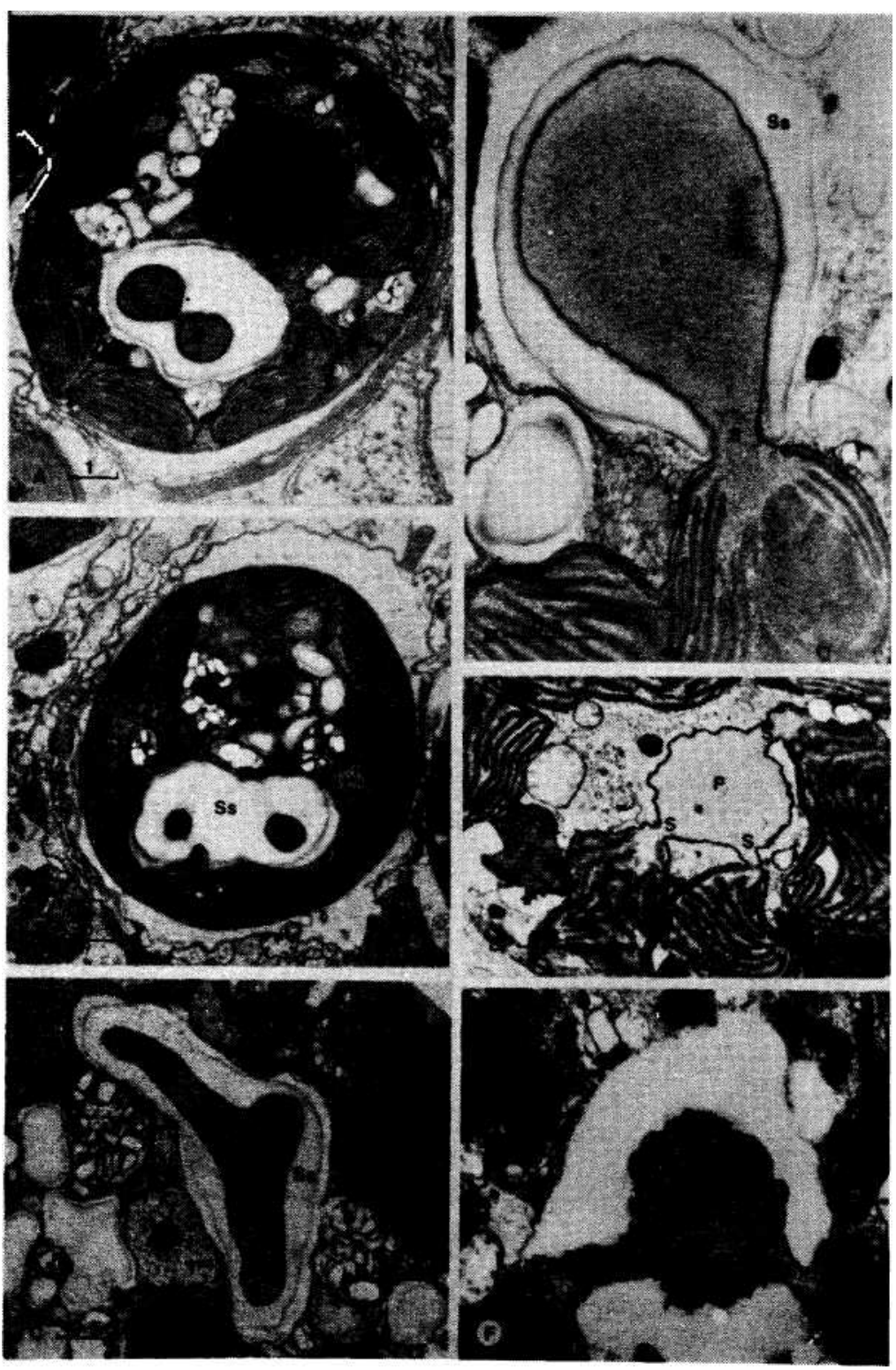

Figure 6. Electron micrograph of the pyrenoid of S. microadriaticum showing the variation of the pyrenoid and the stalk. A and B. The double pyrenoid; C. The branching pyrenoid; $D$. The fine structure of the pyrenoid and the stalk. The lamella does not penetrate to the pyrenoid; E. Pyrenoid with triplet stalk; F. Pyrenoid with doublestalk.

$\mathrm{P}=$ pyrenoid; $\mathrm{S}=$ stalk; $\mathrm{Ss}=$ starch sheat.

Scale bar is in microns. 


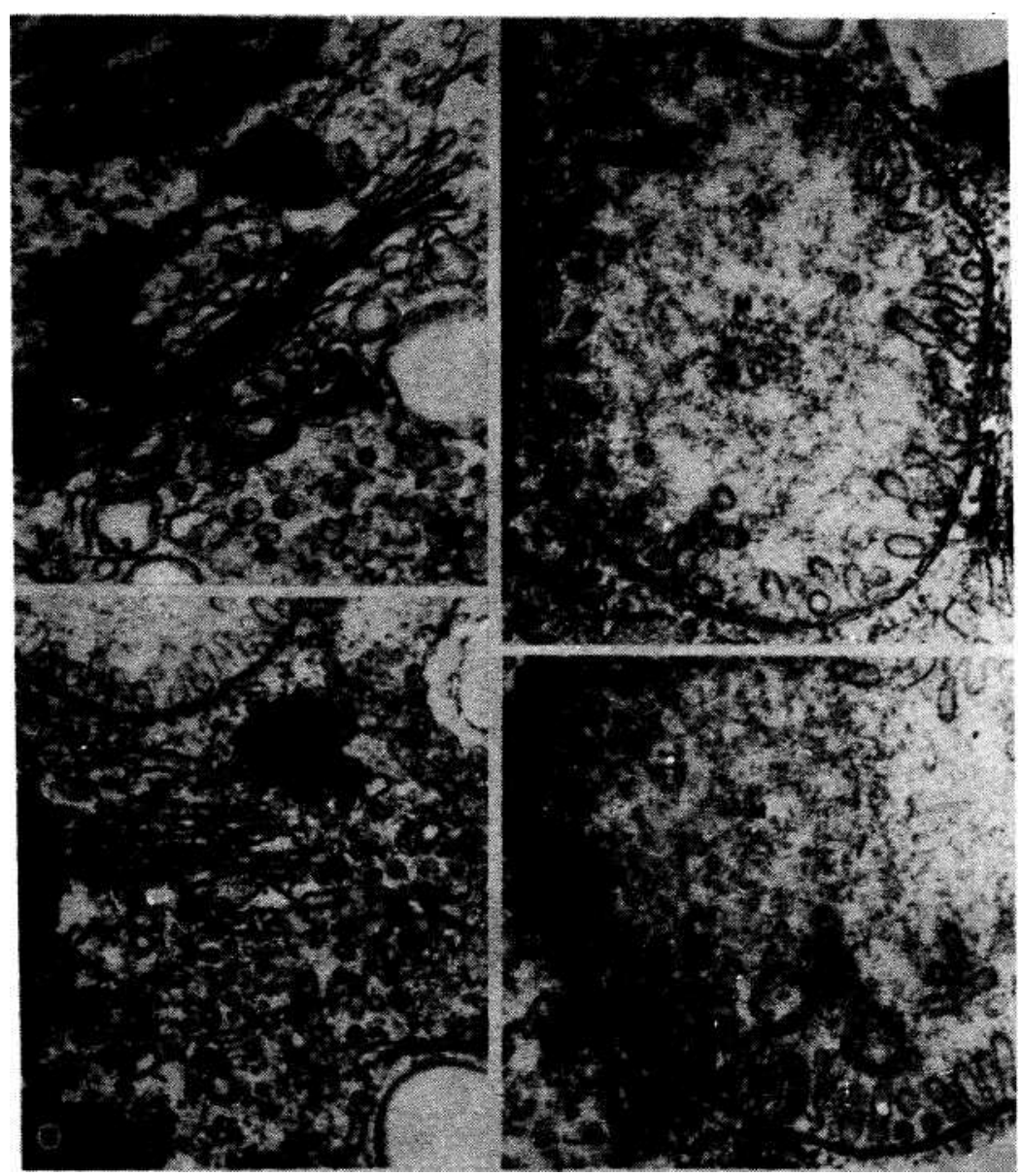

Figure 7. Electron micrograph of the cell organelles of S. microadriaticum showing : A and B. Golgi apparatus with cisternae, vesicles and complex microtubules system indicated by arrow; $\mathrm{C}$ and $\mathrm{D}$. The fine structure of double membranes of the mitochondria. $\mathrm{Cl}=$ chloroplast; $\mathrm{Ct}=$ cristae; $\mathrm{Ga}=$ Golgi apparatus; $\mathrm{M}=$ mitochondrion; $\mathrm{V}=$ vesicle.

Scale bar is in microns. 


\section{SUHARSONO}

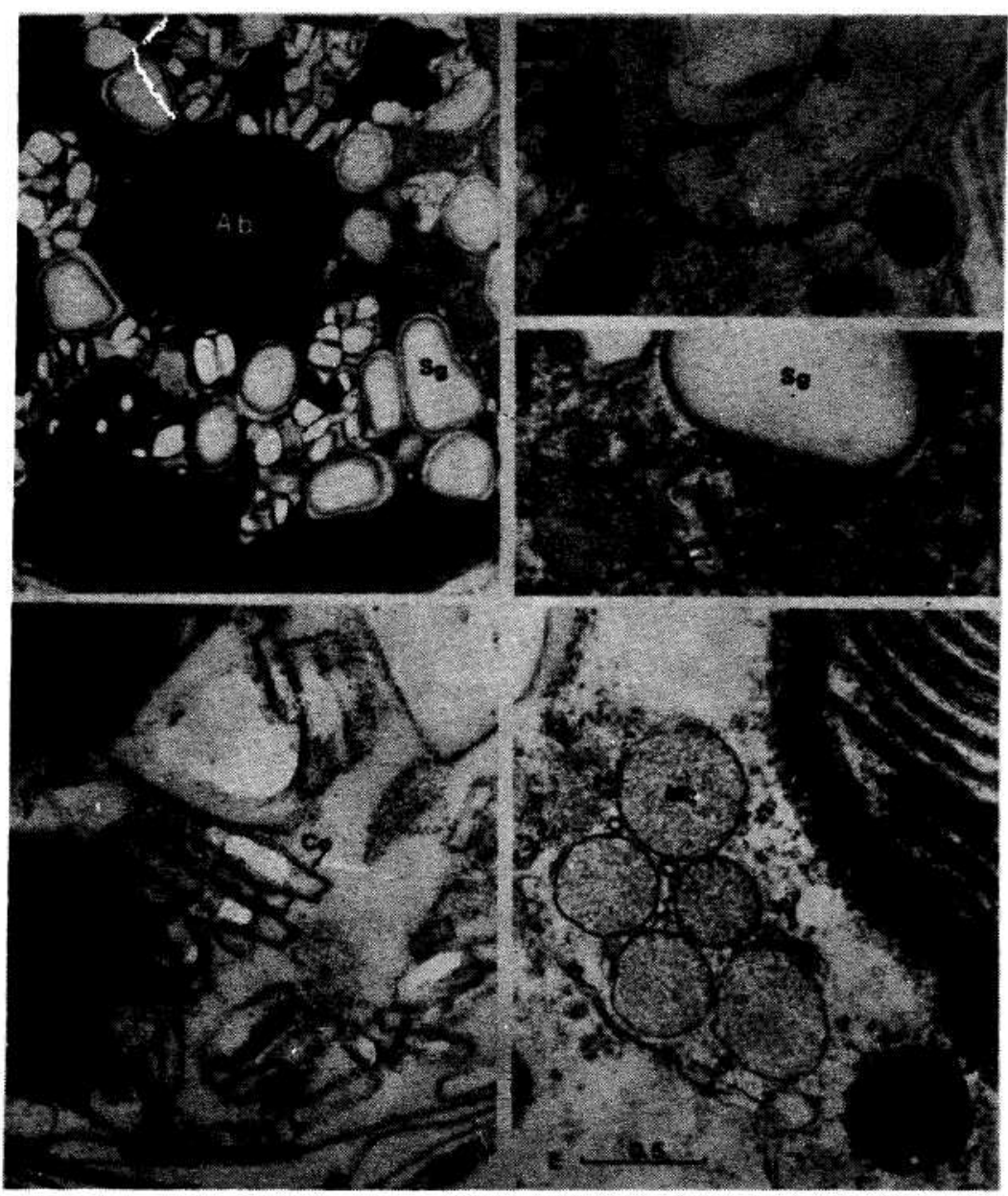

Figure 8. Electron micrograph section of $S$. microadriaticum showing : A. The accumulation body with darkened areas; B. Periodic acid thiocarbohydrazide silver proteinate staining demonstrating strach grains identified by arrows; C. A complex of microtubules with vesicles around the starch grain indicated by arrows; D. The fine structure of crystals of calcium oxalate indicated by arrow; E. microbodies, each enclosed by a single membrane.

$\mathrm{Ab}=$ accumulation body; $\mathrm{Co}=$ calcium oxalate crystals; $\mathrm{M}=$ mitochondrion; $\mathrm{Mb}=$ microbody; $\mathrm{Mt}=$ microtubules; $\mathrm{Sg}=$ starch grains.

Scale bar is in microns. 


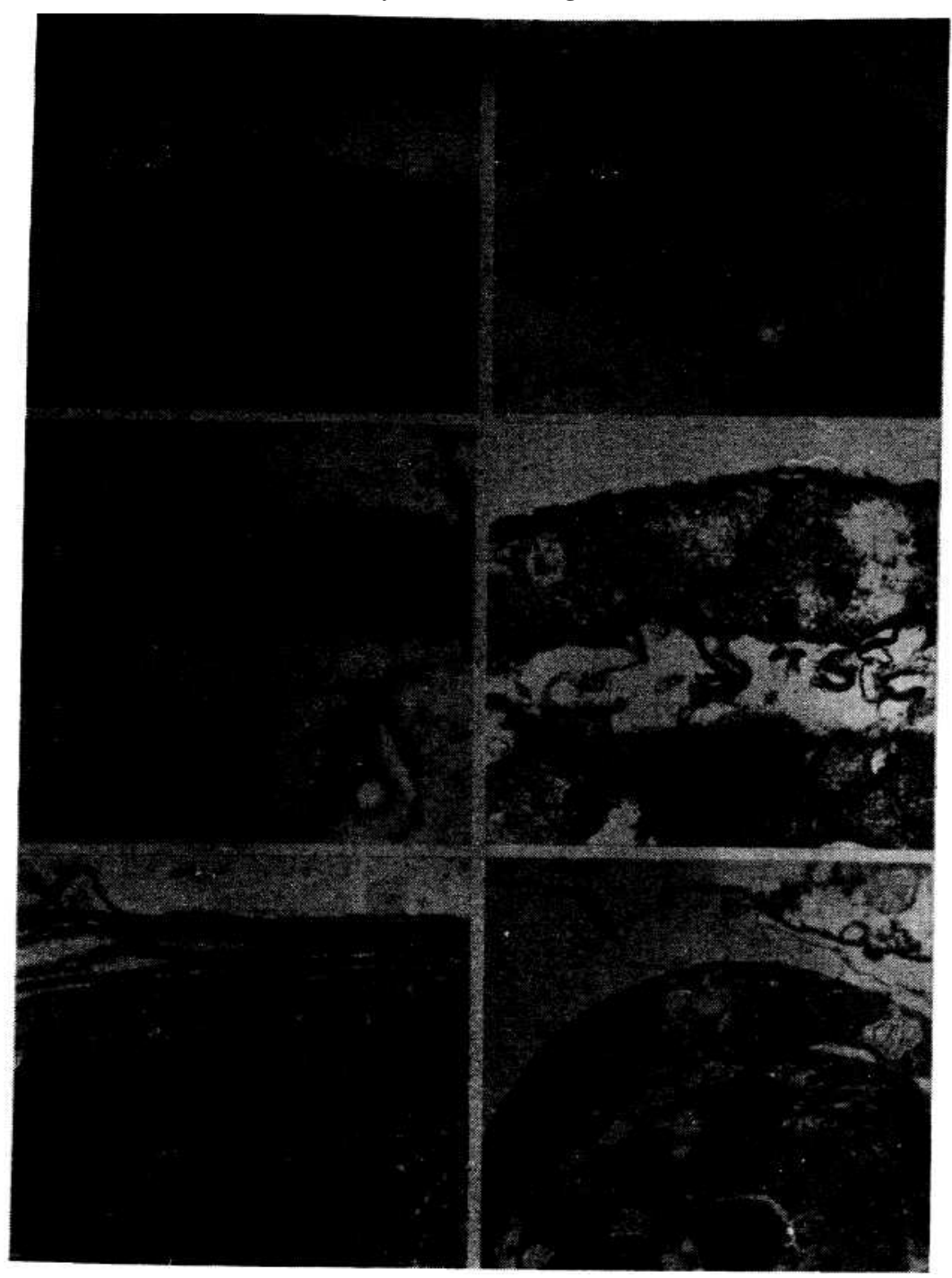

Figure 9. Electron micrograph of the cell walls of S. microadriaticum showing variations in the thickness of the cell Wall. A.The cell wall is composed of outer membrane pellicle, inner pellicle and plasma membrane; B. The plasma membrane is composed of at least two membranes, arxow shows plasma membrane which consist of a continuation of the chloroplast membrane; C. The cell wall consists of a series of cell membranes; D. A thick pellicle composed of plate-like structure with a suture; E. A normal cell wall with an infolding membrane deposited outside the outer membiinc; F. The unusual appearance of the cell membrane.

clm = chloroplast membrane; Ipm = inner pellicle membrane; Om = outer membrane; $\mathrm{P}=$ pellicle; $\mathrm{Pm}$ = pellicle membrane; $\mathrm{S}=$ suture.

Scale bar is in microns. 


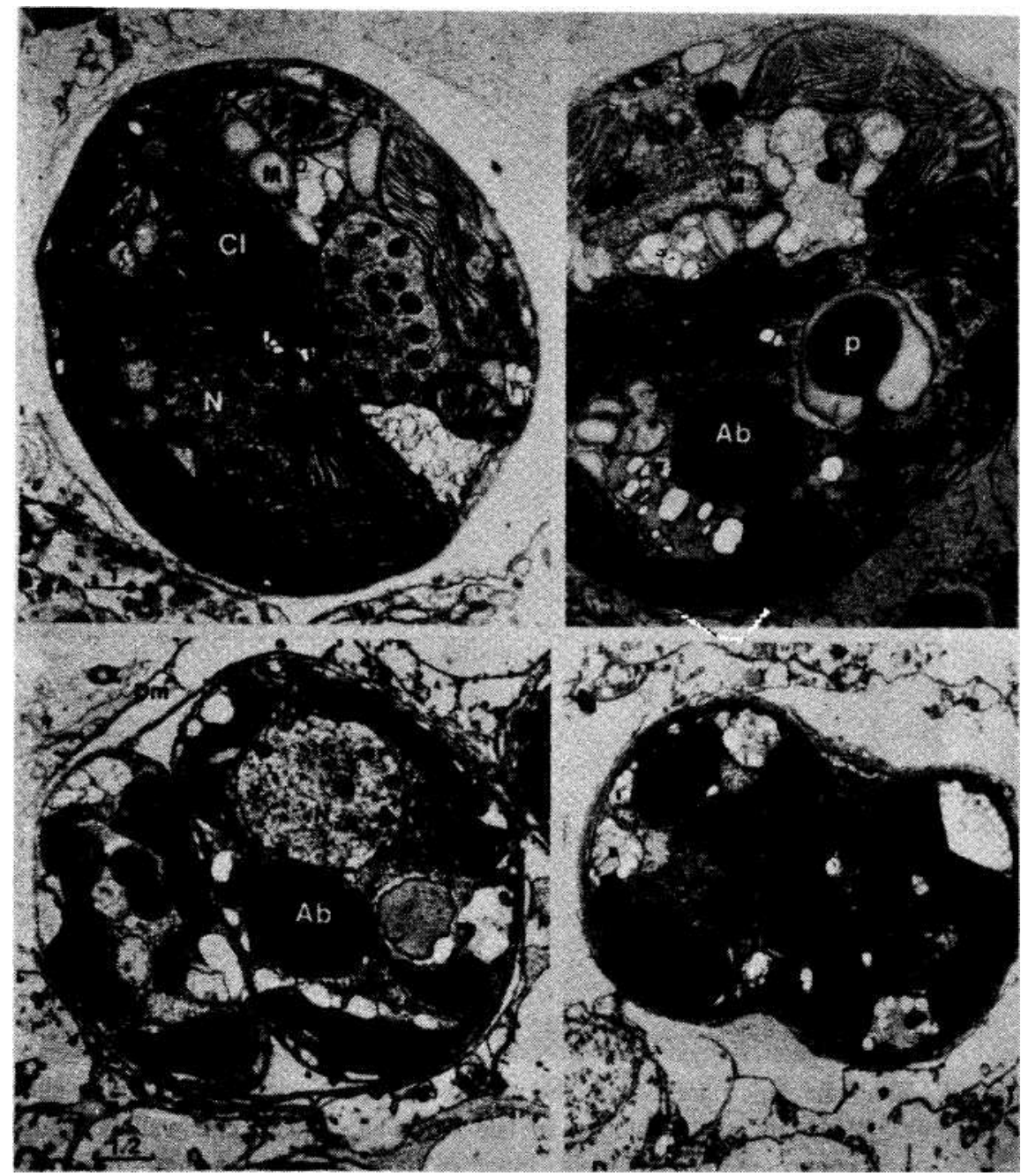

Figure 10. Electron micrograph section of a divided cell of 5. microadriatieum showing: A. The first stage of the division. Cytokinesis occurs after caryokinesis; B. The accumulation body remain in the parent cell; C. Discarded mem branes of the parent cell; D. Two newly formed daughter cells remain cemented in the old cell wall. $\mathrm{Ab}=$ accumulation body; $\mathrm{Cl}=$ chloroplast; $\mathrm{Dm}$ = discarded membranes; $\mathrm{M}^{=}$mitochondrion; $\mathrm{N}=$ nucleus; $\mathrm{P}=$ pyrenoid. Scale bar is in microns. 


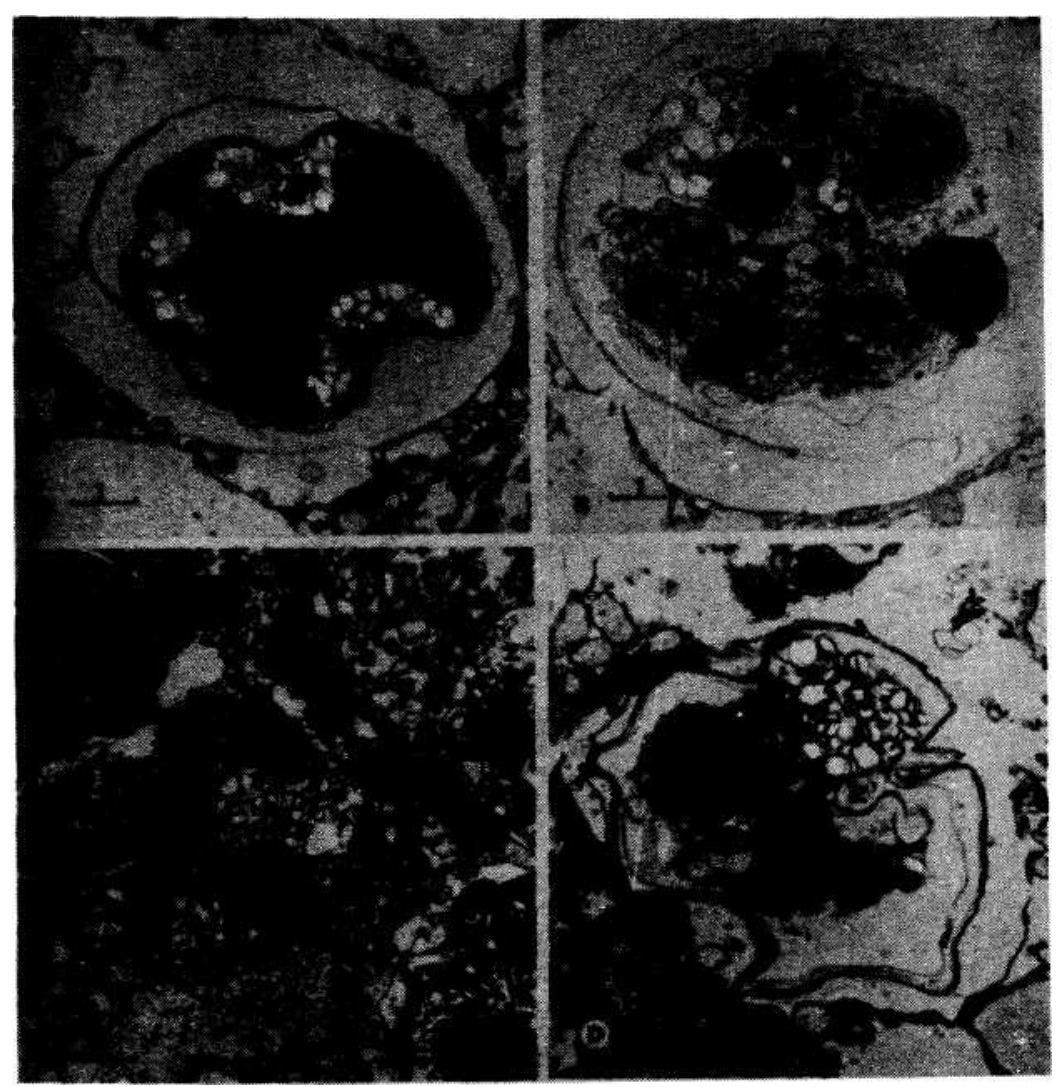

Figure 11. Electron micrograph of the degenerate cell showing : A. The cell wall breaking down in early stage of the degeneration; B. The normal appearance of the degenerate cell, the cell wall breaks down after the disintegration of the content of the cell; C and D. The latest stages of degeneration showing the intact cell wall. $\mathrm{Cl}=$ chloroplast; $\mathrm{Co}=$ calcium oxalate crystal; $\mathrm{N}=$ nucleus; $\mathrm{Z}$ = zooxanthellae. Scale bar is in microns. 